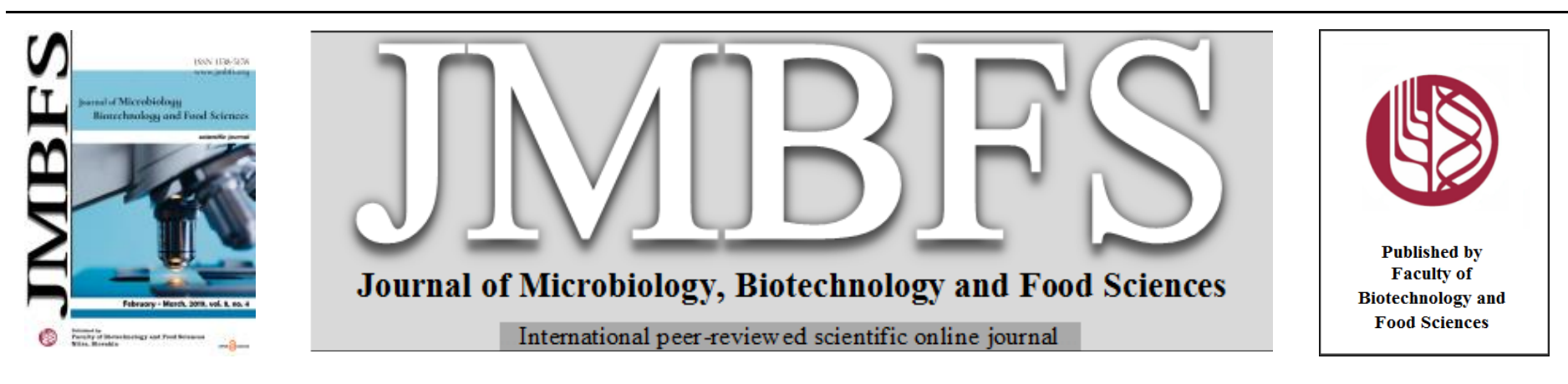

\title{
LUNASIN AND ITS VERSATILE HEALTH-PROMOTING ACTIONS
}

\author{
Hana Ďúranová ${ }^{*}$, Veronika Fialkovál, Jana Bilčíkovál, Norbert Lukáč², Zuzana Kňažická3 \\ Address(es): RNDr. Hana Ďúranová, PhD., \\ ${ }^{1}$ Slovak University of Agriculture in Nitra, The AgroBioTech Research Centre, Tr. A. Hlinku 2, 94976 Nitra, Slovak Republic. \\ ${ }^{2}$ Slovak University of Agriculture in Nitra, Faculty of Biotechnology and Food Resources, Department of Animal Physiology, Tr. A. Hlinku 2, 94976 Nitra, Slovak \\ Republic. \\ ${ }^{3}$ Slovak University of Agriculture in Nitra, Faculty of Biotechnology and Food Resources, Department of Animal Physiology, Tr. A. Hlinku 2, 94976 Nitra, Slovak \\ Republic.
}

*Corresponding author: hana.duranova@uniag.sk

doi: 10.15414/jmbfs.2019.8.4.1106-1110

\section{ARTICLE INFO}

Received 16.8. 2018

Revised 11. 10. 2018

Accepted 15. 11. 2018

Published 1. 2. 2019

\section{Review \\ OPEN $\partial_{\text {ACCESS }}$}

\begin{abstract}
The present review focuses on the potential health benefits of lunasin reported to date. Epidemiological studies on human and animals have demonstrated lower incidence of various types of cancer and other chronic diseases related to consumption of diets containing high amounts of soybean products. Naturally present in soybean, lunasin is the most isolated bioactive peptide with 43 amino acid residues, some of them creating an RGD motif, chromatic-binding helical region and an aspartic acid tail. Due to the three multiple functional domains, the intriguing peptide serves as promising candidate in exerting many-sided health-beneficial actions, such as antioxidant capacity, anti-inflammatory, hypocholesterolemic, and anticancerous activities. Depending on the soybean genotype, the lunasin content in the crop varies from $0.5-8.1 \mathrm{mg} / \mathrm{g}$ of seed. Besides soybean, it has also been identified in wheat Solanum nigrum, rye, barley, amaranth seeds, triticale and quinoa. In the current review, the structure, bioavailability, and molecular mechanisms involved in healthpromoting effects of lunasin have also been summarized.
\end{abstract}

Keywords: lunasin; soybean peptide; antioxidant capacity; anti-inflammation; hypocholesterolemic activity; anticancer activity

\section{INTRODUCTION}

Due to high prevalence of carcinogenic, cardiovascular and metabolic syndromeassociated disorders all over the world, growing scientific studies have been aimed to investigate various natural plant peptides in respect to prevention and treatment of the chronic diseases (Hernández-Ledesma et al., 2013; Liu et al., 2014; Alaswad and Krishnan, 2016; Fernández-Tomé and HernándezLedesma, 2016; Shidal et al., 2016; Janardhanan and Varier, 2018). The bioactive peptides are naturally present in foods or released from the source protein by processing conditions or during gastrointestinal digestion (FernándezTomé and Hernández-Ledesma, 2016). These specific protein fragments possess high tissue affinity, specificity and efficiency in promoting health (Daliri et al., 2017) related to their antihypertensive, antioxidative, antiobesity, immunomodulatory, antidiabetic, hypocholesterolemic and anticancer properties (Singh et al., 2014). One of the most promising and potential anticancer candidate, which was first isolated in 1987 in Japan during the screening of protease inhibitors from soybean is peptide lunasin (Liu et al., 2014). Besides anticancer activity, it has inherent antioxidative and anti-inflammatory effects that could contribute to its chemopreventive action, and it could also play a vital role in regulation of cholesterol biosynthesis in the body (Lule et al., 2015). These various biological functions of the peptide have been clearly demonstrated both in in vitro and in vivo assays (Fernández-Tomé and Hernández-Ledesma, 2016).

\section{LUNASIN STRUCTURE}

Lunasin (from the Tagalog word "lunas" for cure; Hernández-Ledesma and de Lumen, 2008) has been described as 43 amino acid peptide with a molecular weight of $5.5 \mathrm{kDa}$ (Liu et al., 2014; Wan et al., 2017). It corresponds to a small sub-unit peptide encoded within the soybean $2 \mathrm{~S}$ albumin GM2S-1 gene (Seber $\boldsymbol{e} t$ al., 2012; Lule et al., 2015) coding also methione-rich protein, a signal peptide, and a linker peptide (Fernández-Tomé and Hernández-Ledesma, 2016). The unique amino acids sequence of lunasin molecule: SKWQHQQDSCRKQLQGVNLTPC-EKHIMEKIQG-RGD-DDDDDDDD

(Galvez and de Lumen, 1999) with demonstrated activities of all fragments is documented in Figure 1. In summary, the peptide is composed of four regions: (I) fragment with unknown functions, (II) a predicted helix with structural homology to a conserved region of chromatin binding protein for binding to histones $\mathrm{H} 3 / \mathrm{H} 4$, (III) a cell adhesion motif containing arginine (Arg), glycine (Gly) and aspartic acid (Asp) residues called RGD module, and (IV) a critical fragment with antimitotic functions consisting of eight aspartic acids at the C-terminus (Galvez and de Lumen, 1999; Lam et al., 2003; Hernández-Ledesma and de Lumen, 2008; Hernández-Ledesma et al., 2009a). There is accumulating evidence that the last three functional fragments of the peptide are highly responsible for lunasin specific properties. The RGD tripeptide functions as an extracellular matrix to promote the intracellular accessibility of lunasin (Wan $\boldsymbol{e t}$ al., 2017). The important component of lunasin uptake appears to be mediate by internalization via the integrin recycling pathway, with the integrin $\alpha \mathrm{V} \beta 3$ being a key factor (Cam and de Mejia, 2012; Inaba et al., 2014; McConnell et al., 2015). However, it was shown that the role of RGD motif for cellular internalization is cell-line specific, required in C3H 10T1/2 mouse embryo fibroblasts cells (Galvez et al., 2001) but unnecessary in mouse fibroblast NIH3T3 cells (Lam et al., 2003). Beyond this, the RGD motif potentiates the ability of lunasin to compete with integrins to bind with the extracellular matrix consequently suppressing the integrin-mediated signalling pathway, e.g., those that modulates proliferation, migration, invasion (Jiang et al., 2016) and apoptosis of the cells (Lu et al., 2006). Antimitotic effect of lunasin has been attributed to the binding of its poly-D carboxyl end with high negatively charged 8 D-residues to regions of positively charged deacetyled histones and cellular regions, such as hypoacetylated chromatin found in telomeres and kinetochores in centromeres (Fernandéz-Tomé and Hernandéz-Ledesma, 2016). As a result, the kinetochore complex does not form properly, and the microtubules fail to 
attach to the centromeres, leading to mitotic arrest and eventually to cell death (Galvez and de Lumen, 1999).

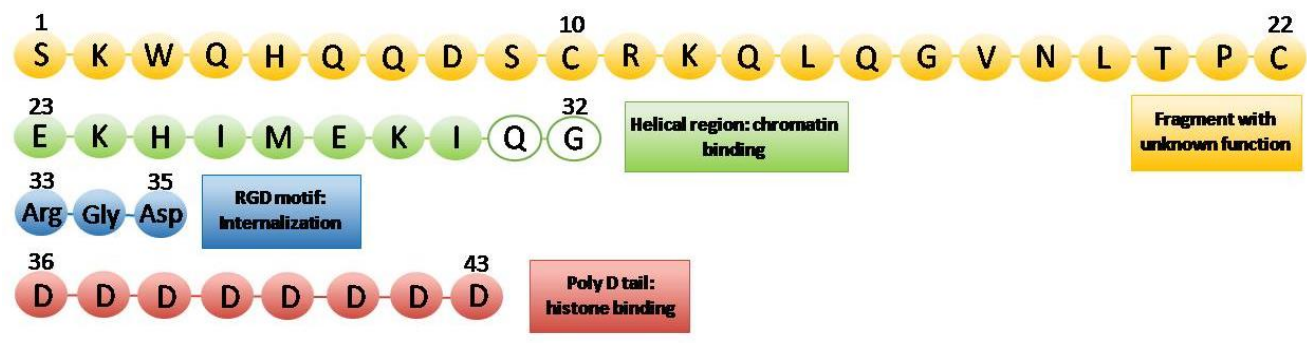

Figure 1 Sequence of 43-amino acids of lunasin peptide with demonstrated functions of each fragment

In terms of the secondary structure, the exact three-dimensional structure of lunasin was characterised by a molecular dynamics study performed by Singh and Bisetty (2012). The study revealed that the peptide has a strong propensity to attain three separate $\alpha$-helical regions flanked by residues $\mathrm{H}^{5}-\mathrm{C}^{10}$ (N-terminus), $\mathrm{C}^{22}-\mathrm{I}^{30}$ (central region) and $\mathrm{D}^{35}-\mathrm{D}^{41}$ (C-terminus) disrupted by few intervening unstructured/extended amino acid residues. RGD motif plays a key role of hinge winding and unwinding the central and C-terminus helical regions of the peptide; however, it does not show any characteristic secondary features. In addition to this, a structural analysis by circular dichroism at $25{ }^{\circ} \mathrm{C}$ has proven that the secondary structure of lunasin is created by $29 \% \alpha$-helix, $28 \% \beta$-strands, $23 \%$ turns and $20 \%$ unordered (Dia et al., 2013).

\section{LUNASIN'S BIOAVAILABILITY}

Biological activity of lunasin depends on its concentration in plant sources, which in turn is affected by cultivar, environmental factors, and processing conditions (Wang et al., 2008). Indeed, the genotype of soybean, as a principal source of the peptide, has been demonstrated to be the main factor of lunasin quantity in soybean seeds (Hernández-Ledesma et al., 2013) ranging from $0.5-8.1 \mathrm{mg}$ lunasin/g seed or $4.4-70.5 \mathrm{mg}$ lunasin/g protein (Liu et al., 2014). Also, the stages of seed development and sprouting influence the lunasin production in this crop. Increased lunasin levels are notable during seed maturation and decreased ones during sprouting period (Park et al., 2005). Besides soybean, lunasin has also been identified in wheat $(0.21-0.29 \mathrm{mg} / \mathrm{g}$ seed; Jeong et al., 2007a), Solanum nigrum L. (1.81 mg/g seed; Jeong et al., 2007b), rye $(0.05-0.15 \mathrm{mg} / \mathrm{g}$ seed; Jeong et al., 2009), barley (0.013-0.099 mg/g seed; Jeong et al., 2010a), amaranth seeds (0.0095-0.0121 mg/g protein; Silva-Sánchez et al., 2008), triticale $(0.43-6.46 \mathrm{mg} / \mathrm{g}$ seed; Nakurte et al., 2012) and recently from quinoa (0.001-0.005 mg/g seed; Ren et al., 2017). According to de Mejia et al. (2003), commercial soy products contain reasonable amounts of lunasin ranging from $5.48 \mathrm{mg}$ lunasin/g protein (defatted soy flour) to $16.52 \mathrm{mg}$ lunasin/g protein (soy concentrate). In addition to this, the daily consumption of $25 \mathrm{~g}$ soy protein, recommended by the Food and Drug Administration (FDA) to reduce coronary heart disease risk (FDA, 1999) supplies approximately $250 \mathrm{mg}$ of lunasin (de Mejia et al., 2003).

Bioavailability of the lunasin is one of the most important assumptions for its therapeutic purposes. Lunasin is very heat-stable peptide, retaining its bioavailability even after 5 minutes of boiling (de Lumen, 2005). Despite its peptide origin it was found that after oral ingestion the bioactive peptide is not completely degraded in the gastrointestinal tract but in intact and bioactive form it reaches various tissues (Hernández-Ledesma et al., 2009a; Muceniece et al., 2016), especially the targets for the most common malignant tumors (i.e., lungs, mammary glands, prostate; Hsieh et al., 2010a). The results of the study by Hsieh et al. (2010a) performed on CD-1 mice receiving $3 \mathrm{H}$-labelled synthetic lunasin mixed with lunasin-enriched soy by gavage have revealed that $30 \%$ of ingested lunasin was distributed in active form into lungs, liver, kidney, mammary glands, prostate and other investigated tissues and organs. Intact state of the intriguing peptide was also extracted from blood and liver of rats fed with lunasin-enriched soy (Jeong et al., 2007c) and lunasin-enriched wheat (Jeong et al., 2007a). Lunasin bioavailability was evaluated in humans, as well. In healthy men who consumed $50 \mathrm{~g}$ of soy protein, an average $4.5 \%$ of biologically active lunasin from the total ingestion was absorbed into the plasma (Dia et al., 2009a). Based on in vitro bioavailability studies simulating gastrointestinal digestion it has been found that lunasin is capable of resistance to function of gastrointestinal enzymes (pepsin, pancreatin) due to naturally present protease inhibitors in food, such as Bowman-Birk protease inhibitor (BBI) and Kunitz trypsin inhibitor (KTI; Jeong et al., 2007b; Park et al., 2007). Hence, both synthetic as well as from food purified lunasin are markedly hydrolysed by pepsin or pancreatin (Fernández-Tomé and Hernández-Ledesma, 2016).

On the cellular level it was reported that internalization of lunasin into the mammalian cells started very early within 5 minutes after in vitro treatment. The cellular internalization of the peptide is primarily mediated by endocytic mechanisms involving integrin signalling, clathrin-coated structures and macropinosomes (Caswell et al., 2009; Cam et al., 2013). After the cell entering, lunasin is initially found in the cytoplasm and in approximately of 18 hours of administration it is localized in the nucleus (Lam et al., 2003).

\section{HEALTH BENEFICIAL EFFECTS OF LUNASIN AND THEIR MOLECULAR MECHANISMS}

\section{Antioxidant activity}

The antioxidant capacity of lunasin mediated through different mechanisms of action has been demonstrated on various in vitro cell models. In lipopolysaccharide (LPS)-stimulated RAW 264.7 macrophages, lunasin treatment led to a significant decreased production of reactive oxygen species (ROS) by the cells due to lunasin-induced inhibition of linoleic acid oxidation and 2,2'-azinobis (3-ethylbenzothiazo-line-6-sulfonic acid) diammonium salt (ABTS) radical scavenging activity of the peptide (Hernández-Ledesma et al., 2009b). The authors hypothesize that the role of lunasin as linoleic acid oxidation inhibitor might be linked to its ability to react with peroxyl radicals resulting in suppression of the propagation cycle of lipid peroxidation. In the study by García-Nebot et al. (2014), the ability of lunasin to neutralize peroxyl and superoxide radicals in intestinal Caco- 2 cells challenged by hydrogen peroxide and tert-buthylhydroxide has been proven. Additionally, protective effect of lunasin peptide purified from Solanum nigrum L. against DNA oxidative damage have been reported to be associated with suppressing the generation of hydroxyl radical followed by blocking fenton reaction between $\mathrm{Fe}^{2+}$ and $\mathrm{H}_{2} \mathrm{O}_{2}$ by chelating iron ferrous ions (Jeong et al., 2010b). According to Zou et al. (2016), the strongest impact on antioxidant activity of peptides (including lunasin) has the composition and the sequence of amino acids in their molecules. Potent action of lunasin is assigned to the presence of Gly, leucine (Leu), phenylalanine (Phe) and proline (Pro) with potent activity against lipid peroxidation (Saiga et al., 2003; Hernández-Ledesma et al., 2009b), and tryptophan (Trp) and cysteine (Cys) residues which were suggested to be responsible for ABTS scavenging activity of the peptide (Hernandéz-Ledesma et al., 2005; Hernández-Ledesma et al., 2009b).

\section{Anti-inflammatory activity}

The anti-inflammatory properties of lunasin have been evidenced through in vitro studies with LPS-stimulated RAW 264.7 murine macrophages (de Mejia and Dia, 2009; Hernandéz-Ledesma et al., 2009b) or LPS-induced THP-1 human macrophages (Cam and de Mejia, 2012) suggesting its actions on key chemical mediators involved in the inflammatory response. In these studies, the capability of lunasin or lunasin-like peptides to inhibit the production of proinflammatory cytokines and markers, such as tumor necrosis factor- $\alpha$ (TNF- $\alpha$ ), interleukine-6 (IL-6), interleukine 1- $\beta$, cyclooxygenase-2, nuclear factor-kappa B $(\mathrm{NF}-\mathrm{KB})$, prostaglandin $\mathrm{E}$, nitric oxide $(\mathrm{NO})$ and others have been observed. The down-regulation of expression of the genes associated with uncontrolled and aberrant inflammation in the macrophages is mediated by lunasin-induced 
suppression of NF-kB pathways (de Mejia and Dia, 2009). The inhibition of Akt-mediated NF- $\mathrm{kB}$ activation was shown to be through potential interactions of lunasin with $\alpha$ V $\beta 3$ (Cam and de Mejia, 2012) and $\alpha 5 \beta 1$ integrins (Dia and de Mejia, 2011a). In addition to this, the mechanism of action by which lunasin or lunasin-like peptides exert their anti-inflammatory activities is based on the cell adhesion motif composed of RGD residues in their molecule structure that binds integrins with high specificity resulting in anti-inflammatory effects (Kuphal $\boldsymbol{e}$ al., 2005). Moreover, the alleviation of allergic airway inflammation symptoms manifested by markedly reduced $\mathrm{Th} 2$ cytokine expression, reduced inflammatory infiltration and cell metaplasia were found in 2 murine models with induced asthma after lunasin inhalation (Yang et al., 2015). The observation suggests lunasin as an anti-inflammatory agent which can be potentially used in asthma therapy or as an adjuvant to enhance the efficacy of allergy immunotherapy.

\section{Anticancer activity}

Lunasin is primarily known as a bioactive peptide due to its ability to exhibit potential anticancer effects (Wan et al., 2017). Chemoprotective properties of lunasin have been confirmed on various cell models in vitro, such as murine NIH/3T3 fibroblast cells (Lam et al., 2003), L1210 leukemia cells (de Mejia et al., 2010), HT-29 colon cancer cells (Dia and de Mejia, 2010), KM12L4 human colon cancer cells (Dia and de Mejia, 2011a), prostate epithelial RWPE-2 cells (Galvez et al., 2011), human liver HepG2 cells (Fernández-Tomé et al., 2014), and MCF-7 and MDA-MB-231 breast cancer cells (Jiang et al., 2016). Lunasin peptide has been shown in in vitro experiments with mammalian cells to suppress transformation of normal cells to cancer ones by oncogenes, such as E1A (Galvez et al., 2001) and Ha-ras (Jeong et al., 2002), and chemical carcinogens 7,12-dimethylbenz(a)anthracene (DMBA) and 3-methylcholanthrene (Galvez $\boldsymbol{e t}$ al., 2001; Hsieh et al., 2010b). This lunasin's ability was also confirmed on DMBA-induced skin tumorigenesis in a mouse model (Galvez et al., 2001). Moreover, the study by McConnell $\boldsymbol{e t}$ al. (2015) revealed that highly purified soybean-derived lunasin has inhibitive effect on anchorage-dependent growth of non-small lung cancer cells (NSCLC), whereas it does not influence two normal bronchial epithelial cell lines. This fact indicates cell-specific aspect of lunasin. The potential underlying mechanisms of lunasin in the prevention and treatment of cancer have been systematically investigated. It was found that all of three unique domains present in sequence of the peptide, i.e., RGD motif, helical domain and poly-aspartic acid tail are implicated in its anticancer activity (Shidal et al., 2017). The tripeptide RGD motif competes with extracellular matrix to interact with integrins $\alpha 5 \beta 1, \alpha \mathrm{V} \beta 3$ and $\alpha \mathrm{V} \beta 5$ (Jiang et al., 2016), widely expressed in different cancer types (Russo et al., 2012), which is crucial in angiogenesis, tumor progression and metastasis. Other mechanisms by which lunasin have shown its anti-neoplasic effects are mediated via its activity inhibiting histone acetylation and its affinity for hypoacetyled chromatin (Fernandéz-Tomé and Hernandéz-Ledesma, 2016). Suppressed histone acetylation is a result of lunasin competition with different histone acetyltransferase enzymes (HATs), such as yGCN5 and PCAF, consequently repressing the cell cycle progression (Jeong et al., 2007a; Jeong et al., 2007b) Since deacetyled histones are absent from wild-type cells, lunasin is not able to disrupt their proliferation or cause their apoptosis, explaining its cell-specific chemopreventive properties (Wan et al., 2017). Antiproliferative and apoptosisinduced effects of lunasin have been demonstrated in some established cancer cell lines, including leukemia (de Mejia et al., 2010), breast (Hsieh et al., 2010c) and colon (Dia and de Mejia, 2011a). The mechanisms of these actions were attributed to lunasin-induced activation of caspase-3 in leukemia L1210 cells (de Mejia et al., 2010), expression of the pro-apoptotic nuclear clusterin in colon cancer HT-29 cells (Dia and de Mejia, 2010), and reduced expression of cyclin $\mathrm{D} 1 / \mathrm{D} 3$, and down-regulation of protein kinase $\mathrm{B} \alpha(\mathrm{PKB} \alpha)$ and activator protein 1 (AP-1) in human breast cancer MDA-MB-231 cells (Hsieh et al., 2010c). The study by Jiang $\boldsymbol{e t}$ al. (2016) have shown that the metastasis of breast cancer cells was suppressed by lunasin through integrin-mediated FAK/Akt/ERK and NF-KB signalling pathways followed by down-regulation of the activity and expression of matrix metalloproteinase-2/-9, possibly via competing with $\alpha \mathrm{V} \beta 3$ or $\alpha \mathrm{V} \beta 5 / \alpha 5 \beta 1$ integrin. Human breast cancer MCF-7 cells treated with lunasin have been found to increase their expression and protein levels of the tumor suppressor phosphatase and tensin homolog PTEN, and to enhance PTEN nuclear localization leading to the induction of PTEN-mediated cellular apoptosis (Pabona et al., 2013). Mechanistic studies using lunasin-sensitive NSCLC cell lines revealed the lunasin blocks cell cycle progression at the G1/S phase interface without inducing apoptosis (McConnell et al., 2015). The authors found that lunasin altered the expression of the G1 specific cyclin-dependent kinase complex components, increased levels of p27Kip1, reduced levels of phosphorylated Akt, and ultimately inhibited the sequential phosphorylation of the retinoblastoma protein (RB). These effects are linked to the inhibition of integrin signalling through $\alpha \mathrm{V}$-containing integrins, strongly supporting the hypothesis that direct effects on integrin signalling represent a major mode of action responsible for lunasin's anticancer activity (Davis and Ianaba, 2016). In human metastatic colon KM12L4 cells, lunasin-arrested cell cycle in G2/M phase with concomitant increase in the expression of cyclin-dependent kinase inhibitors p21 and p27, and lunasin-induced mitochondrial pathway of apoptosis were reported (Dia and de Mejia, 2011b).

\section{Hypocholesterolemic activity}

Lunasin has also been previously proven to possess cholesterol lowering activity that is positively associated with cardiovascular system. The peptide exerts its action for lowering LDL cholesterol levels by directly inhibiting gene expression of 3-hydroxy-3-methylglutaryl coenzyme A (HMG Co-A) reductase to lower cholesterol biosynthesis and by increasing LDL receptor (LDLR) levels to enhance clearance of plasma LDL cholesterol (Galvez, 2012). The underlying mechanism is related to lunasin's ability to bind specifically to histone $\mathrm{H} 3$ and to inhibit H3-Lys14 acetylation by the PCAF (acetyltransferase p300/CBP associated factor) histone acetylase enzyme. The acetylation of $\mathrm{H} 3$ by PCAF is required for transcriptional activation of HMG Co-A reductase, the rate-limiting enzyme for cholesterol biosynthesis in the liver. Therefore, lunasin significantly reduced HMG expression in HepG2 liver cells grown in cholesterol-free media by inhibiting PCAF acetylation of H3-Lys 14. Gu et al. (2017) have revealed two mechanisms by which lunasin increases cell-surface LDLR level and enhanced LDL uptake in $\mathrm{HepG} 2$ cells and $\mathrm{ApoE}^{-/}$mice suggesting its potential role in cholesterol homeostasis maintenance. One of them is mediated via lunasininduced inhibition of proprotein convertase subtilisin/kexin type 9 (PCSK9) expression by down-regulating hepatocyte nuclear factor-1 $\alpha$ (HNF-1 $\alpha$ ). Second one is attributed to PI3K/Akt-mediated activation of SREBP-2 pathway.

\section{CONCLUSION}

Epidemiologic studies indicate that bioactive compounds from plant resources have various biological functions with beneficial effect on health of living organisms. Many phytochemicals act in the prevention and/or treatment of numerous diseases such as cancer. Nowadays, peptides isolated from soya present the study subject of numerous research teams. Lunasin as one of these polypeptides has a specific amino acid sequence which ensures its unique properties. The substance is becoming an increasingly attractive molecule for research purposes mainly due to its biological availability in organism, its antioxidant, anti-inflammatory, anti-cancer and hypocholesterolemic effects potentially usable for therapeutic purposes. For that reason, there is a growing need for application of advanced molecular and proteomic tools to decipher molecular mechanisms of lunasin action in modulation of various diseases and to determine its safety and effectiveness.

Acknowledgments: This research was supported by European Community under project No. 26220220180: Building Research Centre "AgroBioTech and by the Scientific Agency of the Slovak Republic VEGA No. 1/0163/18, APVV-150543 .

\section{REFERENCES}

Alaswad, A. A., Hari B. Krishnan, H. B. (2016). Immunological investigation for the presence of lunasin, a chemopreventive soybean peptide, in the seeds of diverse plants. Journal of Agricultural and Food Chemistry, 64, 2016, 29012909. DOI: https://doi.org/10.1021/acs.jafc.6b00445

Buckley, Ch. D., Pilling, D., Neriquez, N. V., Parsonage, G., Therlfall, K., Scheel-Toelllner, D., Simmons, D. L., Akbar, A. N., Lord, J. M., Salmon, M. (1999). RGD peptides induce apoptosis by direct caspase-3 activation. Nature. 397, 534-539. DOI: https://doi.org/10.2165/00128413-199911770-00017

Cam, A., Gonzalez de Mejia, E. (2012). RGD-peptide lunasin inhibits Aktmediated NF-kappaB activation in human macrophages through interaction with the alphaVbeta3 integrin. Molecular Nutrition \& Food Research, 56, 1569-1581. DOI: https://doi.org/10.1002/mnfr.201200301 
Cam, A., Savaguru, M., Gonzales de Mejia, E. (2013). Endocytic mechanism of internalization of dietary peptide lunasin into macrophages in inflammatory condition associated with cardiovascular disease. PLoS One, 8(9), e72115. DOI: https://doi.org/10.1371/journal.pone.0072115

Caswell, P. T., Vadrevu, S., Norman, J. C. (2009). Integrins: Masters and slaves of endocytic transport. Nature Reviews Molecular Cell Biology, 10, 843-853. DOI: https://doi.org/10.1038/nrm2799

Daliri, E. B., Oh, D. H., Lee, B. H. (2017). Bioactive Peptides. Foods, 6(5), 1-21. Davis, K. R., Inaba, J.-I. (2016). Lunasin-amultifactorial anticancer peptide from soybean. International Journal of Cancer Therapy and Oncology, 4(2), 4218 DOI: $\underline{\text { https://doi.org/10.14319/ijcto.42.18 }}$

de Lumen, B. O. (2005). Lunasin: a cancer-preventive soy peptide. Nutrition Reviews, 63(1), 16-21. DOI: https://doi.org/10.1111/j.1753-4887.2005.tb00106.x de Mejia, E. G., Bradford, T., Hasler, C. (2003). The anticarcinogenic potential of soybean lectin and lunasin. Nutrition Reviews, 61, 239-246. DOI: https://doi.org/10.1301/nr.2003.jul.239-246

de Mejia, E. G., Dia, V. P. (2009). Lunasin and lunasin-like peptides inhibit inflammation through suppression of NF-kappaB pathway in the macrophage. Peptides, 30, 2388-2398. DOI: https://doi.org/10.1016/j.peptides.2009.08.005 de Mejia, E. G., Wang, W., Dia, V. P. (2010). Lunasin, with an arginine-glycineaspartic acid motif, causes apoptosis to L1210 leukemia cells by activation of caspase-3. Molecular Nutrition \& Food Researches, 54, 406-414. DOI: https://doi.org/10.1002/mnfr.200900073

Dia, V. P., Torres, S., de Lumen, B. O., Erdman, J. W., de Mejia, E. G. (2009a) Presence of lunasin in plasma of men after soy protein consumption. Journal of Agricultural and Food Chemistry, 57, 1260-1266. DOI: https://doi.org/10.1021/jf803303k

Dia, V. P., Wang, W., Oh, V. L., de Lumen, B. O., de Mejia, E. G. (2009b). Isolation, purification and characterization of lunasin from defatted soybean flour and in vitro evaluation of its anti-inflammatory activity. Food Chemistry, 114, 108-115. DOI: https://doi.org/10.1016/j.foodchem.2008.09.023

Dia, V. P., de Mejia, E. G. (2010). Lunasin promotes apoptosis in human colon cancer cells by mitochondrial pathway activation and induction of nuclear clusterin expression. Cancer Letters, 295, 44-53. DOI https://doi.org/10.1016/j.canlet.2010.02.010

Dia, V. P., Gonzalez de Mejia, E. (2011). Lunasin potentiates the effect of oxaliplatin preventing outgrowth of colon cancer metastasis, binds to alpha5beta1 integrin and suppresses FAK/ERK/NF-kappa B signaling. Cancer Letters, 313, 167-180. DOI: https://doi.org/10.1016/j.canlet.2011.09.002

Dia, V. P., Frankland-Searby, S., Del, H. F. L., Garcia, G., Gonzalez de Mejia E. (2013). Structural property of soybean lunasin and development of a method to quantify lunasin in plasma using an optimized immunoassay protocol. Food Chemistry, 138, 334-341. DOI: https://doi.org/10.1016/j.foodchem.2012.09.101 Fernández-Tomé, S., Ramos, S., Cordero-Herrera, I., Recio, I., Goya, L. Hernández-Ledesma, B. (2014). In vitro chemo-protective effect of bioactive peptide lunasin against oxidative stress in human HepG2 cells. Food Research International, 62, 793-800. DOI: https://doi.org/10.1016/j.foodres.2014.04.054 Fernández-Tomé, S., Hernández-Ledesma, B. (2016). An update on lunasin research, a bioactive seed peptide for health promotion. Govil, J. N. (ed.): Recent Progress in Medicinal Plants, 43 - Phytoterapeutics II. Editorial: Studium Press LLC, 331-352.

Food and Drug Administration (FDA), Department of Health and Human Services. (1999). 21 CFR Part 101: Food labeling: health claims; soy protein, and coronary heart disease. Federal Register, 64, 57700- 57733.

Galvez, A. F., de Lumen, B. O. (1999). A soybean cDNA encoding a chromatinbinding peptide inhibits mitosis of mammalian cells. Nature Biotechnology, 1999, 495-500. DOI: https://doi.org/10.1038/8676

Galvez, A. F., Chen, N., Macasieb, J., de Lumen, B. O. (2001). Chemopreventive property of a soybean peptide (lunasin) that binds to deacetylated histones and inhibits acetylation. Cancer Research, 61, 7473-7478.

Galvez, A.F., Huang, L., Magbanua, M.M.J., Dawson, K. and Rodriguez, R.L. (2011). Differential expression of thrombospondin (THBS1) in tumorigenic and nontumorigenic prostate epithelial cells in response to a chromatin-binding soy peptide. Nutrition and Cancer, 63: 623-36. DOI: https://doi.org/10.1080/01635581.2011.539312

Galvez, A. F. (2012). Identification of lunasin as the active component in soy protein responsible for reducing LDL cholesterol and risk of cardiovascular disease. Circulation, 126, A10693.
García-Nebot, M. J., Recio, I., Hernández-Ledesma, B. (2014). Antioxidant activity and protective effects of peptide lunasin against oxidative stress in intestinal Caco-2 cells. Food and Chemical Toxicology, 65, 155-161. DOI https://doi.org/10.1016/j.fct.2013.12.021

Gu, L., Wang, Y., Xu, Y., Tian, Q., Lei, G., Zhao, Ch., Gao, Z., Pan, Q., Zaho, W., Nong, L., Tan, S. (2017). Lunasin functionally enhances LDL uptake via inhibiting PCSK9 and enhancing LDLR expression in vitro and in vivo. Oncotarget, 8(46), 80826-80840. DOI: https://doi.org/10.18632/oncotarget.20590 Hernández-Ledesma, B., Miralles, L., Amigo, M., Ramos, M., Recio, I. (2005). Identification of antioxidant and ACE-inhibitory peptides in fermented milk. Journal of the Science of Food and Agriculture, 85, 1041-1048. DOI: https://doi.org/10.1002/jsfa.2063.

Hernández-Ledesma, de Lumen, B. O. (2008). Lunasin: A Novel Cancer Preventive Seed Peptide. Perspective in Medical Chemistry, 2008, 75-80. DOI: https://doi.org/10.4137/pmc.s372

Hernández-Ledesma, B., Hsieh, C.-C., de Lumen, B. O. (2009a). Lunasin, a novel seed peptide for cancer prevention. Peptides, 30, 426-430. DOI: https://doi.org/10.1016/j.peptides.2008.11.002

Hernández-Ledesma, B., Hsieh, C.-C., de Lumen, B. O. (2009b). Antioxidant and anti-inflammatory properties of cancer preventive peptide lunasin in RAW 264.7 macrophages. Biochemical and Biophysical Research Communications, 390, 803-808. DOI: https://doi.org/10.1016/j.bbrc.2009.10.053

Hernández-Ledesma, $\quad$ B., Hsieh, C.-C., de Lumen, B. O. (2013). Chemopreventive Properties of Peptide Lunasin: A Review. Protein and Peptide Letters, 20, 424-432. DOI: https://doi.org/10.2174/0929866511320040006

Hsieh, C.-C., Hernández-Ledesma, B., Jeong, H. J., Park, J. H., de Lumen, B. O. (2010a). Complementary roles in cancer prevention: protease inhibitor makes the cancer preventive peptide lunasin bioavailable. PLOS ONE, 5, e8890. DOI: https://doi.org/10.1371/journal.pone.0008890

Hsieh, C. C., Hernández-Ledesma, B., de Lumen, B. O. (2010b). Soybean peptide lunasin supresses in vitro and in vivo 7,12-dimethylbenz[a]anthraceneinduces tumorigenesis. Journal of Food Science, 75(9), H311-316. DOI https://doi.org/10.1111/j.1750-3841.2010.01861.x

Hsieh, C. C., Hernandez-Ledesma, B., de Lumen, B. O. (2010c). Lunasin, a novel seed peptide, sensitizes human breast cancer MDA-MB-231 cells to aspirinarrested cell cycle and induced apoptosis. Chemico-Biological Interactions, 186, 127-134, DOI: https://doi.org/10.1016/j.cbi.2010.04.027

Hsieh, C. C., Martinéz-Villaluenga, C., de Lumen, B. O., Hernández-Ledesma B (2017). Updating the research on the chemopreventive and therapeutic role of the peptide lunasin. Journal of the Science of Food and Agriculture, 98(6), 20702079. DOI: https://doi.org/10.1002/jsfa.8719

Inaba, J., McConnell, E. J, Davis, K. R. (2014). Lunasin sensitivity in non-small cell lung cancer cells is linked to suppression of integrin signaling and changes in histone acetylation. International Journal of Molecular Science, 15(12), 2370523724. DOI: https://doi.org/10.3390/ijms151223705

Janardhanan, Y., Varier. M. N. (2018). Isolation and Papain Digestion of Novel Antifungal Peptides from Red Radish (Raphanus Raphanistrum subsp Sativus) and Analysis of Selective Cytotoxicity for Cancer Treatment. Journal of Microbiology, Biotechnology and Food Sciences, 7(6), 615-622. DOI https://doi.org/10.15414/jmbfs.2018.7.6.611-614

Jeong, H. J., Jeong, J. B., Kim, D. S., Park, J. H., Lee, J. B., Kweon, D. H., Chung, G. Y., Seo, E. W., de Lumen, B. O. (2007a). The cancer preventive peptide lunasin from wheat inhibits core histone acetylation. Cancer Letters, 255, 42-48. DOI: https://doi.org/10.1016/j.canlet.2007.03.022

Jeong, J. B., Jeong, H. J., Park, J. H., Lee, S. H., Lee, J. R., Lee, H. K., Chung, G. Y., Choi, J. D., de Lumen, B. O. (2007b). Cancer-preventive peptide lunasin from Solanum nigrum L. inhibits acetylation of core histones $\mathrm{H} 3$ and $\mathrm{H} 4$ and phosphorylation of retinoblastoma protein $(\mathrm{Rb})$. Journal of Agricultural and Food Chemistry, 55, 10707-10713. DOI: https://doi.org/10.1021/jf072363p

Jeong, H. J., Jeong, J. B., Kim, D. S., de Lumen, B. O. (2007c). Inhibition of core histone acetylation by the cancer preventive peptide lunasin. Journal of Agricultural and Food Chemistry, 55, p. 632-637. DOI: https://doi.org/10.1021/jf062405u

Jeong, H. J., Lee, J. R., Jeong, J. B., Park, J. H., Cheong, Y. K., de Lumen, B. O. (2009). The cancer preventative seed peptide lunasin from rye is bioavailable and bioactive. Nutrition and Cancer, 61, 680-686. DOI https://doi.org/10.1080/01635580902850082

Jeong, H. J., Jeong, J. B., Hsieh, C. C., Hernández-Ledesma, B., de Lumen, B. O (2010a). Lunasin is prevalent in barley and is bioavailable and bioactive in 
in vivo and in vitro studies. Nutrition and Cancer, 62, 1113-1119. DOI: https://doi.org/10.1080/01635581.2010.515529

Jeong, J. B., de Lumen, B. O., Jeong, H. J. (2010b). Lunasin peptide purified from Solanum nigrum L. protects DNA from oxidative damage by suppressing the generation of hydroxyl radical via blocking fenton reaction. Cancer Letters, 293, p. 58-64. DOI: https://doi.org/10.1016/j.canlet.2009.12.019

Jiang, Q., Pan, Y., Cheng, Y., Li, H., Liu, D., Li., H. (2016). Lunasin suppresses the migration and invasion of breast cancer cells by inhibiting matrix metalloproteinase-2/-9 via the FAK/Akt/ERK and NF- $\mathrm{KB}$ signaling pathways. Oncology Reports, 36, 253-262. DOI: https://doi.org/10.3892/or.2016.4798

Kuphal, S., Bauer, R., Bosserhoff, A. K. (2005). Integrin signalling in malignant melanoma. Cancer and Metastasis Reviews, 24(2), 195-222. DOI 10.1007/s10555-005-1572-1

Lam, Y., Galvez, A., de Lumen, B. O. (2003). Lunasin Suppresses E1AMediated Transformation of Mammalina Cells but Does Not Inhibit Growth of Immortalized and Established Cancer Cell Lines. Nutrition and Cancer, 47, 8894. DOI: https://doi.org/10.1207/s15327914nc4701_11

Liu, J., Jia, S.-H., Kirberger, M., Chen, N. (2014). Lunasin as a promising healthbeneficial peptide. European Review for Medical and Pharmacological Sciences, 18, 2070-2075.

Lu, X., Lu, D., Scully, M. F., Kakkar, V. V. (2006). Integrins in drug targetingRGD templates in toxins. Current Pharmaceutical Design, vol. 12, 2006, p. 2749-2769. DOI: https://doi.org/10.2174/138161206777947713

Lule, V. K., Garg, S., Pophaly, S. D., Hitesh, Tomar, S. K. (2015). Potential Health Benefits of Lunasin: A Multifaceted Soy-Derived Bioactive Peptide. Journal of Food Science, 80, R485-R494. DOI: https://doi.org/10.1111/1750$\underline{3841.12786}$

McConnell, E. J., Devapatla, B., Yaddanapudi, K., Davis, K. R. (2015). The soybean-derived peptide lunasin inhibits non-small cell lung cancer cell proliferation by supressing phosphorylation of the retinoblastoma protein Oncotarget, 6(7), 1-14. DOI: 10.18632/oncotarget.3080

Muceniece, R., Namniece, J., Nakurte, I., Jekabsons, K., Riekstina, U., Jansone, B. (2016). Pharmacological research on natural substances in Latvia: Focus on lunasin, betulin, polyprenol and phlorizin. Pharmacological Research, 113(Pt B), 760-770. DOI: https://doi.org/10.1016/j.phrs.2016.03.040

Nakurte, I., Klavins, K., Kirhnere, I., Namniece, J., Adlere, L., Matvejevs, J., Kronberga, A., Kokare, A., Strazdina, V., Legzdina, L., Muceniece, R. (2012). Discovery of lunasin peptide in triticale (X Triticosecale Wittmack). Journal of Cereal Science, 56, 510-514. DOI: https://doi.org/10.1016/j.jcs.2012.04.004

Pabona, J. M., Dave, B., Su, Y., Montales, M. T., de Lumen, B. O., de Mejia, E. G., Rahal, O. M., Simmen, R. C. (2013). The soybean peptide lunasin promotes apoptosis of mammary epithelial cells via induction of tumor suppressor PTEN: similarities and distinct actions from soy isoflavone genistein. Genes \& Nutrition, 8(1), 79-90. DOI: 10.1007/s12263-012-0307-5.

Park, J. H., Jeong, H. J., de Lumen, B. O. (2005). Contents and bioactivities of lunasin, bowman-birk inhibitor, and isoflavones in soybean seed. Journal of Agricultural and Food Chemistry, 53(20), 7686-7690. DOI: 10.1021/jf0506481

Park, J. H., Jeong, J., de Lumen, B. O. (2007). In vitro digestibility of the cancerpreventive soy peptides lunasin and BBI. Journal of Agricultural and Food Chemistry, 55, 10703-10706.DOI: https://doi.org/10.1021/jf072107c

Ren, G., Zhu, Y., Shi, Z., Li, J. (2017). Detection of lunasin in quinoa (Chenopodium Quina Willd). And the in vitro evaluation of its antioxidant and anti-inflammatory activities. Journal of the Science of Food and Agriculture, 97(12), 4110-4116. DOI: https://doi.org/10.1002/jsfa.8278

Ruoslahti, E. (1996). RGD and other recognition sequences for integrins. Annual Review of Cell and Developmental Biology, 12, 697-715. DOI: https://doi.org/10.1146/annurev.cellbio.12.1.697

Russo, M. A., Paollilio, M., Sanchez.-Hernandez, Y., Curti, D., Cuisani, E., Serra, M., Colombo, L., Schinelli, S. (2012). A small-molecule RGD-integrin antagonist inhibits cell adhesion, cell migration and induces anoikis in glioblastoma cells. International Journal of Oncology, 42, 83-92. DOI: https://doi.org/10.3892/ijo.2012.1708

Saiga, A., Tanabe, S., Nishimura, T. (2003). Antioxidant activity of peptides obtained from porcine myofibrilar proteins by protease treatment. Journal of Agricultural and Food Chemistry, 51, 3661-3667. DOI: https://doi.org/10.1021/jf021156g

Seber, L. E., Barnett, B. W, Davis, K. R. (2012). Scalable Purification and Characterization of the Anticancer peptide from Soybean. PLoS One, 7(4) e35409. DOI: https://doi.org/10.1371/journal.pone.0035409
Shidal, C., Al-Rayyan, N., Yaddanapudi, K., Davis, K. R. (2016). Lunasin is a novel therapeutic agent for targeting melanoma cancer stem cells. Oncotarget, 7 , 84128-84141. DOI: https://doi.org/10.18632/oncotarget.11554

Shidal, CH., Inaba, J.-I., Yaddanapudi, K., Davis, K. R. (2017). The soy-derived peptide Lunasin inhibits invasive potential of melanoma initiating cells. Oncotarget, 8(15), 25525-25541. DOI: https://doi.org/10.18632/oncotarget.16066 Silva-Sánchez, C., de la Rosa, A. P., León-Galván, M. F., de Lumen, B. O., de León-Rodríguez, A., de Mejía, E. G. (2008). Bioactive Peptides in Amaranth (Amaranthus hypochondriacus) Seed. Journal of Agricultural and Food Chemistry, 56, 1233-1240. DOI: 10.1021/jf072911z

Singh, P., Bisetty, K. (2012). A Molecular Dynamics Study of Lunasin. South African Journal of Chemistry, 65, 115-124.

Singh, B. P., Vij, S., Hati, S. (2014). Functional significance of bioactive peptides derived from soybean. Peptides, 54, 171-179. DOI: https://doi.org/10.1016/j.peptides.2014.01.022

Villard, V., Kalvuzhniv, O., Riccio, O., Potekhin, S., Melnik, T. N., Kajava, A. V., Ruegg, C., Corradin, G. (2006). Synthetic RGD-containing alpha-helical coiled coil peptides promote integrin-dependent cell adhesion. Journal of Peptide Science, 12, 206-212. DOI: https://doi.org/10.1002/psc.707

Wan, X., Liu, H., Sun, Y., Zhang, J., Chen, X., Chen, N. (2017). Lunasin: A promising polypeptide for the prevention and treatment of cancer. Oncology Letters, 13, 3997-4001. DOI: https://doi.org/10.3892/ol.2017.6017

Wang, W., Dia, V. P., Vasconez, M., de Mejia, E. G. (2008). Analysis of soybean protein-derived peptides and the effect of cultivar, environmental conditions, and processing on lunasin concentration in soybean and soy products. Journal of AOAC International, 91, 936-946.

Yang, X., Zhu, J., Tung, C.-Y., Gardiner, G., Wang, Q., Chang, H.-C., Zhou, B. (2015). Lunasin alleviates allergic airway inflammation while increases antigenspecific tregs. PLOS ONE, 10, e0115330. DOI: https://doi.org/10.1371/journal.pone.0115330

Zou, T.-B., He, T.-P., Li, H.-B., Tang, H.-W.,Xia, E.-Q. (2016) The StructureActivity Relationship of the Antioxidant Peptides from Natural Proteins. Molecules, 21, 72. DOI:10.3390/molecules21010072 